\title{
気管支鏡検査による小児期慢性気管支感染症の新知見 一非拡張性化膿性気管支漏について一
}

\section{I まえがき}

気管支鏡検查は小児科領域に於いては新生児 の気道内粘液・羊水の吸引, 気管支内異物の剔 出等には欠くべからざるものであり，最近では 肺リンパ腺結核症に於いても，リンパ腺の穿孔 による潰瘍, 肉芽, 症痕, 狭窄或は無気肺等の 診断にも広く応用される様になつてきている。

これに較べて気管支肺化膿症に関する気管支 鏡検査の応用の報告は少なく, 僅かに Diamonds, S. and Van Loon, E.L. ${ }^{1)}$ の報告がある に過ざない。

私達は数ヶ月以上に亘つて頑固な咳嗽，喀痰 を主訴として来院し，所謂慢性気管支炎と診断 される患児の中に気管支抎張症, 肺膿瘍等の肺 化膿症に移行する以前に種々の中間的段階が女 るものと考兄，慢性の咳濑，喀痰を主訴とする 患児について気管支鏡検查 (以下 Brs.) を中心 にして検査した。その結果, 胸部普通写真に於 いては肋膜癒着像を除いて異常なく, 気管支造 影法（以下 Brg.）によつて子気管支の拨張像 は認められないが, Brs.を行うと限局性に或 る気管支領域に膿性分泌物の流出が認められ， 仏学派の云了非抁張性化膿性気管支漏 (Bronchorrhee's purulentes sans ektasie $)^{2}$ 飞相当す る新しい病像として 3 症例を認めた。

我々の報告する症例は本邦に於ける本症の最 初の報告例と考えられる。

\section{II 検査対象並びに検査方法}

Brs.施行 1 時間前に年令相当の薬用量の 2 倍

* 東京大学医学部耳鼻咽喉科学教室

（主任 切替一郎教授）

**東京大学医学部小児科学教室

（主任 高津忠夫教授）
*戸塚 元 吉 佐 藤 正 夫

**時田源一島信幸

量のルミナール，燐酸コデインを頓用させ，エ ーテルによる全身麻酔の下に乳児用或は小児用 のジャクソン型気管支直達鏡を挿入した。

一部に麻酔前処置として Chlorpromazine, Pyrethiazine, Opystan の Cocktail の年令相当 量を使用した。

Brs 時気管内捲綿子により気管支分泌物を採 取培養し，一部は塗沫標本につき papanicolaou 染色法を施行した。

Brs 後 $60 \%$ 気管支造影用ウロコリンを用いて Brg を施行した。

気管支分泌物より分離培養した細菌について は, 固定後感応錠により Sulfathiazol SM, AM, TM, CM, PC に対する感受性試験を行つた。

検査の対象としては昭和 30 年 1 月より昭和 32 年 5 月迄に，項固な豩嗽，喀咨を主訴として東 大小児科外来を訪れた19例の患児について検査 した。

年令は 1 才 6 カ月より 11 才 4 カ月に亘り, 男 児 5 例, 女児14例である。

\section{III 検 査成 績}

Brs. 及び Brg.の結果を中心にして綜合的に 診断した結果, 検査対象19例の診断は,

$\begin{array}{ll}\text { 慢性気管支炎 } & 9 \text { 例 } \\ \text { 非拡張性化膿性気管支漏 } & 3 \text { 例 } \\ \text { 慢 性 肺 炎 } & 3 \text { 例 } \\ \text { 気管支搪張症 } & 3 \text { 例 } \\ \text { 滲出性肋膜炎 } & 1 \text { 例 }\end{array}$

であり，5ち非抾張性化膿性気管支漏の 2 症例 を含めて一部については著者等の一人時田 ${ }^{3)}$ が 既に発表したが，茲では更にその後に非抾張性 化膿性気管支漏と診断された症例を中心にして 報告する。 


$$
\text { 症例。⑤ } 5 \text { 才 } 10 \text { 力月女览。 }
$$

既往歴。出産満期安産, 出生時体重 $2820 \mathrm{~g}$ 。

3 才 9 ガ月の時麻疹に罹患した以外に著患を 知らず，百日咳，肺炎，猩紅熱に罹患した既往 むない。

現病歷。1956年 7 月初旬頃より認むべき誘因 もない鲻に湿性咳嗽が出始める様になつてき た。

8 月頃より咳嗽と共に吐く様になり，某病院 にて Nebulizer による吸入療法を 2 週間受け, 軽快したが，12月頃より检嗽は再び増加し，

Achromycin を一週間服用し，喛嗽は一時消失 した様であるが，1957年 1 月中句より再び夜間 喰嗽が強く, 分泌物が喉頭にからさ様な咳嗽が 出る様になり, 黄色粘液性の喀痰が 1 日に湯吞 茶椀に半量程度喀出される様になつてきた。

2 月23日より食欲も急に減退し始め, 1 日 2 〜 3 回浐嗽と共に吐く樣になり，2月25日東大 小児科に入院した。

入院時所見。

体格栄養中程度。脈搏数 92 , 緊張良, 規則 的。呼吸は規則的で平常。咽頭は軽度に発赤し ているが扁桃腺肥大は認められない。

左側頸部リンパ腺は小豆大のものを数ヶ触知 する。

心臓所見。心尖搏動は左側乳線上第 5 肋間, 心濁音界は正常, 心雑音は聴取し得ない。

肺臓所見。胸部は打診上異常なく, 聴診上左 前下部に非有響性の中水泡音を僅かに聴取す る。

腹部は肝 1 横指触知する以外に異常所見を認 めず, その他皮䖉, 毛髪, 瞳孔, 口腔粘膜, 神 経学的所見等沤異常を認めない。

入院時検査所見。

ツ反応（2000 倍液）陰性。

赤沈值：30分值 $45 \mathrm{~mm}, 1$ 時間值74。

血液像 : 赤血球数 $553 \times 10^{4}, \mathrm{Hb}$ 值 $15.5 / \mathrm{dl}$, $\mathrm{MCH} 28$, 白血球数 9100 , 白血球百分率, 好塩 基球 $0 \%$ ，好酸球 $0 \%$ ，桿状核 $24 \%$ ，分葉核 49 $\%$ ，大リンパ球 $11 \%$ ，小リンパ球 $12 \%$ ，単球 $4 \%$, 形質球 $0 \%$ 。

尿所見, 異状なく, 䔬便潜血反応陰性, 寄生 虫卵浮遊法で陰性。
喀痰培養によりグラム陽性の $\alpha$ 溶血を示す 球菌を分離した。

胸部レ線所見。

背腹方向撮影では左側肋骨横隔膜角に淡い肋 膜癒着を思わせる三角形の陰影を認め, 心臓陰 影の左半部の内部に下葉背側にゆく気管支透明 带の㹡大或は気管支壁の肥厚を思わせる所見を 認めた。(図 1)

側面撮影では図 2 の如く, 上下葉間肋膜癒着 像を認める以外に異常所見を認めない。

図 1 普通撮影

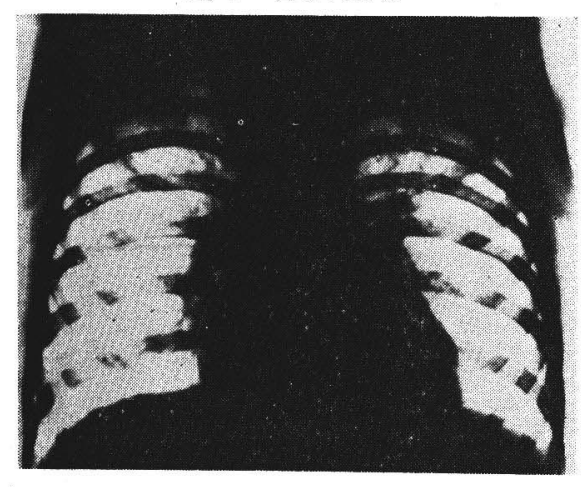

因 2 側面撮影

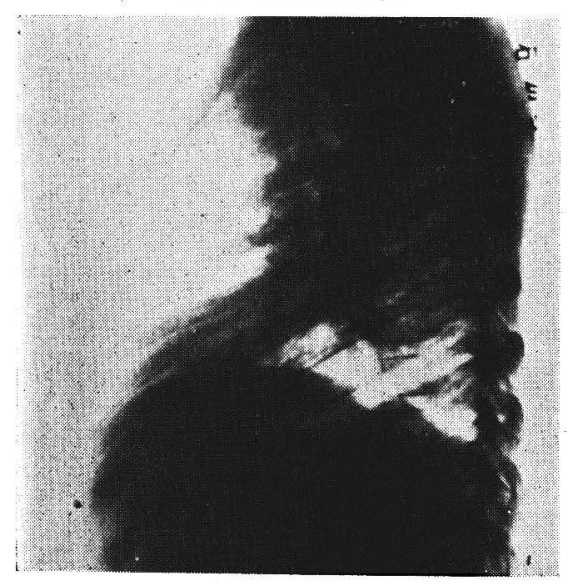

断層撮影像。

routine film で気管支の拡張像が推定される 様な所見を得たので左下肺を背側より図 3 の如 く $3,4,5,6,7 \mathrm{~cm}$ の部分で断層撮影を施行した が，肺内病巣を思わせる異常所見もなく，又搪 張像も認められない。

そこで 2 月27日，エーテル麻醉の下にBrsを 
図 3 断層像

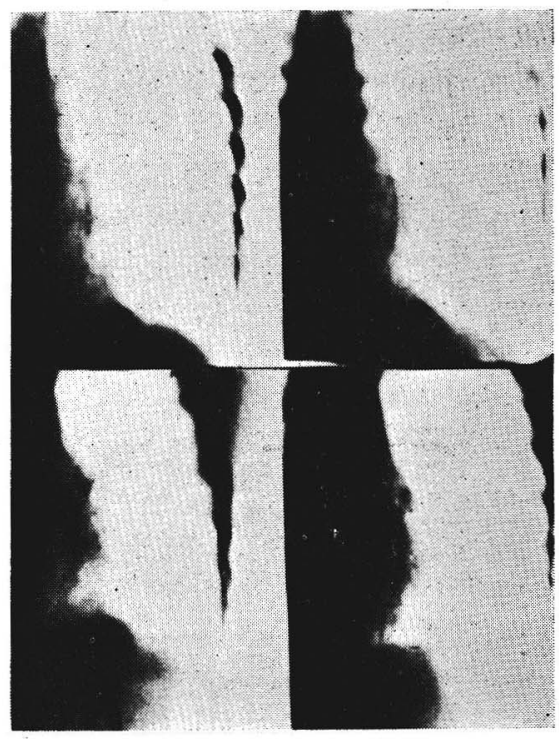

施行した。

気管支鏡所見。気管の粘膜には膿性分泌物の 大量の附着が認められ，左側主気管支の粘膜は 肥厚して軟骨輪は認められず truncus inferior 以下は黄白色の膿汁を認めた。

右側主気管支は僅かに粘液性分泌物を認める 以外飞異常所見なく，粘膜の肥厚も認められな w。

Brs 終了後 $69 \%$ 油性ウロコリン 7cc を左側 主気管支に注入し，Brg を施行したが気管支の 抎張像は証明されなかつた。(図 $4 \mathrm{a}$, 図 $4 \mathrm{~b}$ )

以上の検查所見より, 本例は非拡張性化膿性 気管支漏と診断された。

Brs 施行時採取した膿汁を家鬼血液寒天に培 養した結果, Neisseria Catarrhalis 及びグラム 陰性桿菌の 2 種を分離した。

治療として 3 月 2 日より Chloromycetin $750 \mathrm{mg}$ を 8 時間毎 3 回経口投与し Penicillin 10 万単位, Streptomycin $0.25 \mathrm{~g}$, Trypsillin 1 万単位を 2cc の緩衝液に溶解させて, Aerosol inhalation を朝夕 2 回施行した。

3 月 4 日には咳嗽は著明に減少し， 3 月 7 日 には食欲も良好となり，12日には赤沈值 1 時間 值 $6 \mathrm{~mm}$ となり, 喀痰は全く消失し, 胸部理学 的所見も消失した。

10 日以後は Chloromycetin の経口投与は中
図 4 a 気管支造影図(腹背)

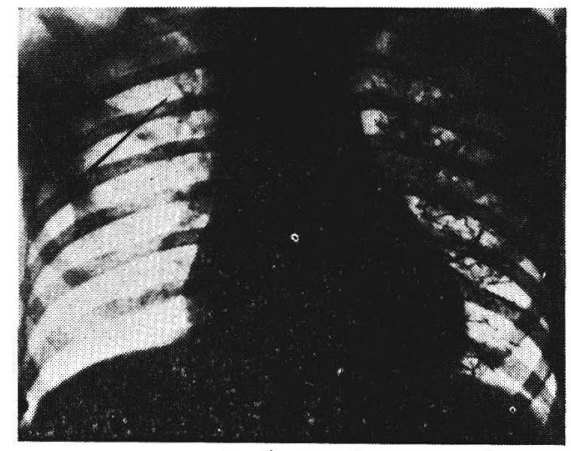

図 $4 \mathrm{~b}$ 同 (側面)

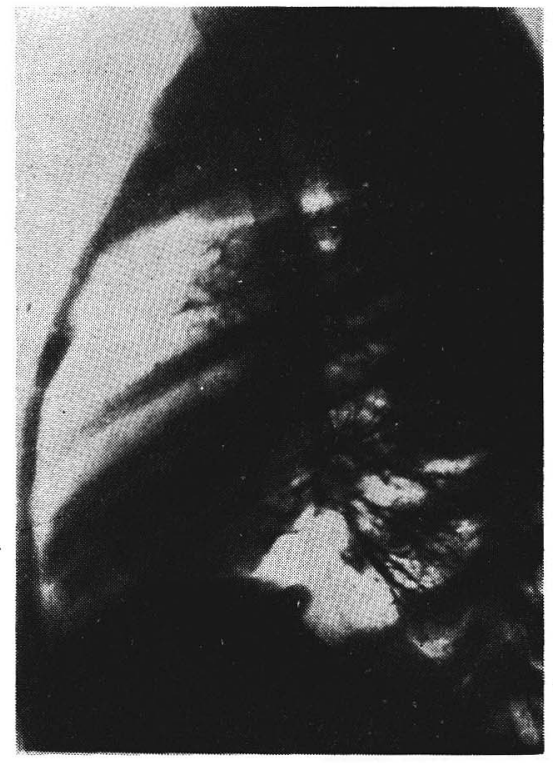

止し, Aerosol inhalation を朝夕 2 回継続し, 3 月18日には全治退院した。

\section{IV 考按}

気管支㹡張症の成因については，素因説，分 泌物渚溜説, 神経筋肉系麻痺説, 肺組織の線維 化による牽引説, 気管支内圧負荷説, 無気肺 説, 気管支閉塞説, 感染説, アレルギー説, 気 管支肺壊死説等諸説が林立している状態である が，気管支壁の感染が重要な役割を演じている ことは否定できない。

私達は $\mathrm{Brs}$ 及び Brg を施行した19例の検查 成績及びその経験から，上気道感染から気管支 肺化膿症汽の進展様式として表 1 の如く 3 つの 経路を想定した。 


\section{第 1 表}

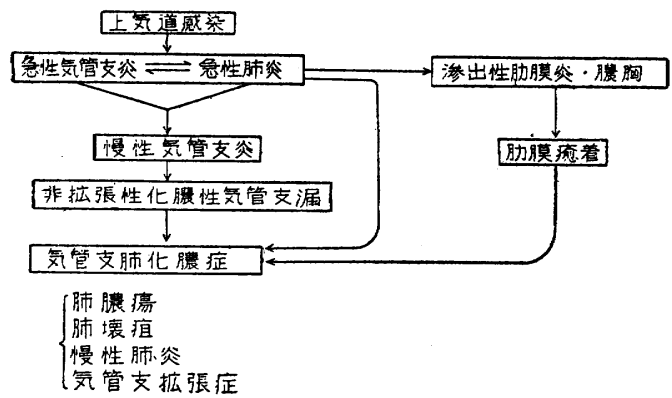

感染の出発点は表 1 の如く血行性感染の特殊 な場合を除汗ば上気道感染であり，上気道感染 は急性及び慢性の感染の何れをも含んで括り， 副鼻腔炎, アデノイド，扁桃腺肥大症等の慢性 上気道感染と気管支肺化膿症との関係について は Aschner, P., Field, C. G., ${ }^{5)}$ Steinmeyer und Kathe, ${ }^{6)}$ Walsch, T. W. and Meyer, O. O. ${ }^{7)}$ Clerf, L.H., ${ }^{8)}$ Goodale, R. L. ${ }^{9)}$ 等多〈の報 告があり，又実験的にも Brock, R.C. ${ }^{10)}$ は鼻 腔内に注入した Moljodol が睡眠中肺区域特に 右上葉又は右下葉の基底肺区域に到達すること をレ線学的に証明し, 鼻咽腔の膿汁が気管支肺 化䁸症の原因になり得る点を指摘した。

表 1 の様に上気道感染より急性気管支炎及び 急性肺炎を併発した場合, 肺病巣の融解吸收機 転が遅延し不充分であれば，気管支感染，線維 化，癖痕性収縮による気管支狭窄或は無気肺等 の機転により，慢性脑炎或は気管支㹡張症がお こる。

又急性肺炎に併発乃至続発して生ずる滲出性 肋膜炎乃至膿胸の 治癒後生じた胁膜癒着によ り，気管支の機械的牽引，狭窄により分泌物の 漖溜をきたし，二次的細菌感染を扣こして気管 支肺化膿症に移行することもある。

この様に気管支の感染は慢性肺化膿症の成立 に最も重要な役割を演じているものと考えられ るが，急性の上気道感染から慢性気管支肺化膿 症に移行する迄には種々の中間的段階が存在す るものと考えられる。

茲に報告した如く，限局された気管支領域に 膿性分泌物の流出の認められる非抎張性化膿性 気管支漏は，慢性気管支炎から一歩進んで気管 支拨張症に移行する以前の中間的段階として極
めて重要な病像と考号られるが，従来本邦では その報告の見られなかつたものである。

本症は routine film では胁膜癒着像を除け ば巽常なく, 又気管支造影法, 断層撮影法でも 肺内異常所見を認め得ず，Brsによつてのみ異 常所見る診断することができるものである

Brs 検查時採取した気管支分泌物より貴重な 細菌学的材料を得る上からも，Brs は本症の診 断，治療上に久くことができない。

\section{V 結 語}

慢性の豩嗽，喀痰を主訴とし，胸部理学的検 查, 一般臨床検査及び胸部 $\mathrm{X}$ 線検査で診断の明 らかでなかつた19名の患児に気管支造影法及び 気管支鏡検査を施行し， 3 例に非拡張性化膿性 気管支漏を認めた。

本例は本邦に於ける最初の報告例であり，気 管支抎張症に進展する中間的段階としての本症 の診断及び治療上の意義について考察した。

\section{引用交献}

1) Diamonds, S. and Van Loon, E. L. : J. A. M. A., 118, 771, 1942

2) Metras, H. et Charpin, J. : Le cathétérisme bronchique. Vigot Freies, Paris. 1953

3) 時田：日本小児科学会雑誌, $61: 1: 45 \sim 50$, 昭 和 32 年

4) Aschner, P. : Ann. Surg., $75: 3: 321 \sim 333$, 1922

5) Field, C. G. : Am. J. Med. Sc., $159: 3:$ 442 449, 1920

6) Steinmeyer und Kathe : Beitr. Klin. Tbk. 64 : 2, 275 286, 1926

7) Walsch, T. W. and Meyer, O. O. : Arch. int. Med., $61: 6: 890 \sim 897,1938$

8) Clerf, L. H, : Laryngoscope, $44: 7: 568 \sim 571$, 1934

9) Goodale R. L. : Ann. Otol. Rhin. \& Laryng $47: 2: 347 \sim 359,1938$

10) Brock, R. C. : Thorax, $5: 5,1950$

本論文の要旨は第 9 回日本気管食道科学会総会に 扣いて報告した。

稿を終るに当り御指導御校閲を頂いた東京大学医 学部耳鼻咽喉科学教室切替一郎教授, 東京大学医学 部小児科学教室高津忠夫教授に梁甚の謝意を表する 